\title{
A NEW SPECIES OF CALLAEUM (MALPIGHIACEAE) FROM PUEBLA, MEXICO
}

\author{
WiLLIAM R. ANDERSON \\ University of Michigan Herbarium, 3600 Varsity Drive, Ann Arbor, \\ Michigan 48108-2287, U.S.A.
}

\begin{abstract}
Callaeum johnsonii (Malpighiaceae), from the state of Puebla, Mexico, is described as new and illustrated. It is similar to C. clavipetalum D. M. Johnson of Oaxaca, differing in characters of the stipules, leaves, bracts, and bracteoles.
\end{abstract}

Key words: Callaeum, Malpighiaceae, Mexico, Puebla.

\section{RESUMEN}

Se describe e ilustra a Callaeum johnsonii (Malpighiaceae) como una nueva especie del estado mexicano de Puebla. Morfológicamente, $C$. johnsonii es similar a C. clavipetalum D. M. Johnson de Oaxaca, pero difiere en caracteres de las estípulas, hojas, brácteas y bractéolas.

Palabras clave: Callaeum, Malpighiaceae, México, Puebla.

\section{INTRODUCTION}

Callaeum Small is a small genus of neotropical Malpighiaceae characterized by marginal leaf glands, epipetiolar stipules, mostly hairy yellow petals, heteromorphic stamens with the posterior three bearing reduced anthers, transversely expanded stigmas, and samaras bearing lateral wings. The flowers are usually clustered in few-flowered umbels or dense corymbs. Niedenzu (1928) treated these plants as species of Mascagnia, but Johnson (1986) argued that Callaeum deserves recognition as distinct from Mascagnia. A recent molecular study (Davis et al., 2002) provided evidence that Mascagnia sensu Niedenzu is polyphyletic. In that study, Callaeum septentrionale (Adr. Juss.) D. M. Johnson was placed in a strongly 
supported clade with two other species of "Mascagnia", both of which will soon be moved to segregate genera; that clade is far removed from Mascagnia sens. str.

Johnson (1986) recognized ten species in Callaeum, seven with geographic ranges from Mexico to Nicaragua and three in South America. For many years I have held two fruiting specimens from Puebla that were clearly not assignable to any described species, hoping that this eleventh species would be found with flowers. Unfortunately, that has not happened, and I have now decided that it would be best to propose a name for the species and publish a description and illustration of it.

\section{NEW SPECIES}

Callaeum johnsonii W. R. Anderson, sp. nov. Fig. 1.

Liana gracilis lignosa; lamina foliorum majorum $5-6.2 \mathrm{~cm}$ longa, $1.8-3 \mathrm{~cm}$ lata, elliptica, eglandulosa vel prope basim utrinque 1 glandula parva marginali instructa, supra parce sericea mox glabrata, subtus \pm pertinaciter tomentosa; petiolus 2-5.5 mm longus, eglandulosus; stipulae $0.5-0.8 \mathrm{~mm}$ longae, prope medium petioli portatae; inflorescentia ex 3 umbellis 4-floris constans; bracteae bracteolaeque 2.5$7 \mathrm{~mm}$ longae, 0.8-2 $\mathrm{mm}$ latae, anguste ellipticae vel lanceolatae, patentes; stigma transversaliter expansum; samara alis lateralibus $21-22 \mathrm{~mm}$ altis et $14-15 \mathrm{~mm}$ latis, ala dorsali $11 \mathrm{~mm}$ alta et $4-5 \mathrm{~mm}$ lata.

Slender woody vine, the stems loosely sericeous or tomentose, eventually glabrescent; lamina of larger leaves 5-6.2 cm long, $1.8-3 \mathrm{~cm}$ wide, elliptical, cuneate at base, acute, obtuse, or slightly acuminate at apex, eglandular or bearing on each side 1 small more or less cylindrical gland on margin within $1 \mathrm{~cm}$ of base, adaxially thinly sericeous to soon glabrate with the hairs sessile or subsessile and straight or sinuous, abaxially persistently tomentose to belatedly glabrescent with the hairs very fine, translucent, stalked, the crosspieces 1.5-2.5 mm long, sinuous and nonparallel but not strongly twisted, numerous but not nearly dense enough to hide surface of lamina, the lateral veins 4-5 on each side of midrib; petiole 2-5.5 mm long, densely appressed-tomentose to glabrate in age, eglandular; stipules $0.5-0.8$ $\mathrm{mm}$ long, shaped like tapered upward-curving fingers, tomentose to glabrate, borne on petiole near middle (from somewhat below to well above middle); inflorescence a terminal cluster of three 4-flowered umbels, the axes tomentose; bracts $2.5-7 \mathrm{~mm}$ long, $0.8-2 \mathrm{~mm}$ wide, narrowly elliptical or lanceolate, spreading, eglandular, adaxially glabrate, abaxially loosely sericeous, the larger ones short-petiolate and resembling narrow miniature leaves; peduncle 2-3.5 $\mathrm{mm}$ long, persistently 
Anderson: A new species of Callaeum from Puebla, Mexico
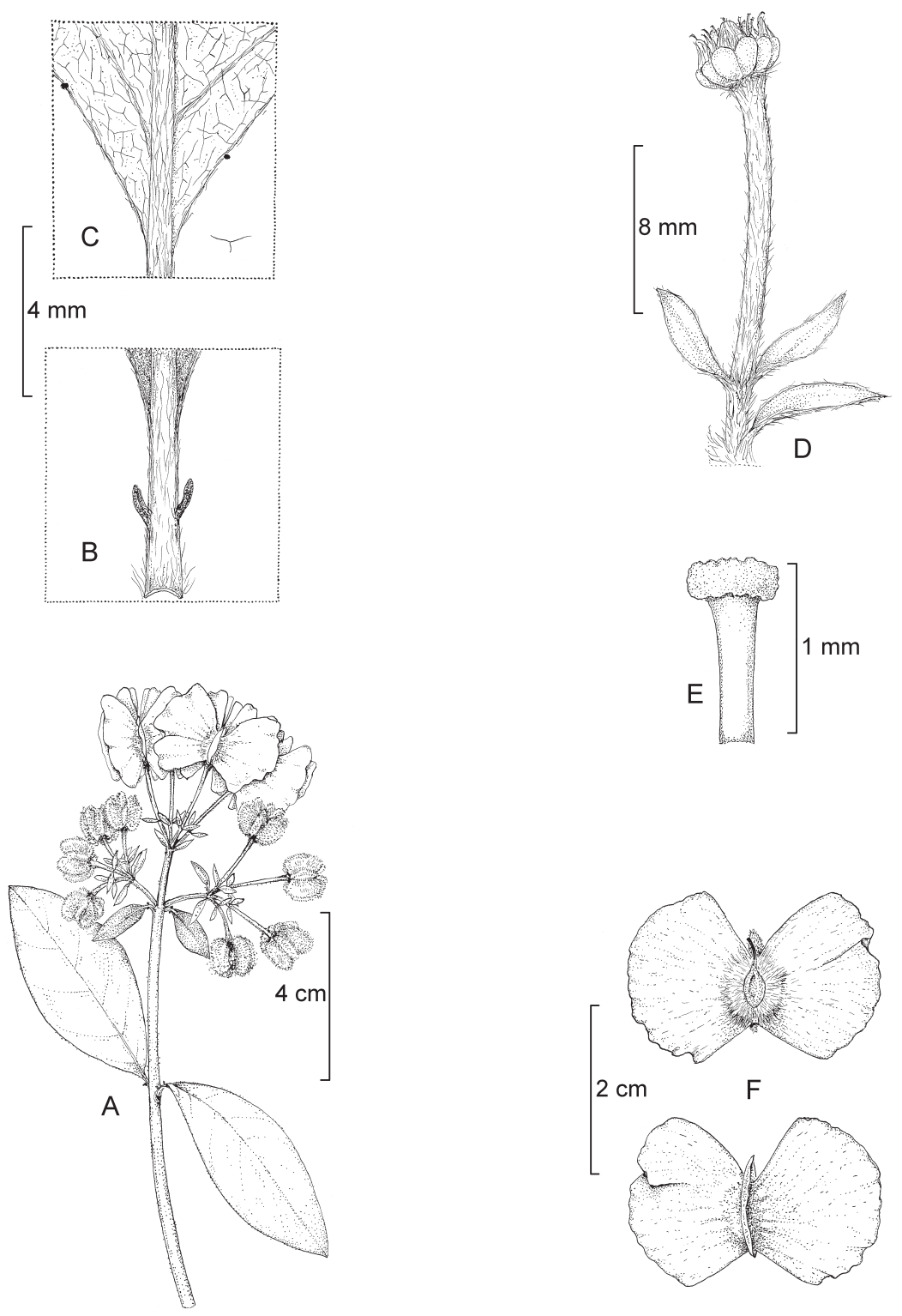

Fig. 1. Callaeum johnsonii W. R. Anderson. A. Fruiting branch; B. Adaxial view of petiole, to show stipules; C. Abaxial view of base of lamina, to show vesture and marginal glands; D. Old flower, to show large bract and bracteoles; E. Adaxial view of apex of style, to show transversely expanded stigma; F. Samara, adaxial view (above) and abaxial view (below). AE, Cavender s. n., WIS; F, Miranda 2549, MEXU. 
tomentose; bracteoles like bracts or somewhat smaller, borne at apex of peduncle; pedicel 13-16 mm long in fruit, tomentose to somewhat glabrescent; sepals revolute in old flowers, the lateral 4 abaxially biglandular, the anterior eglandular; corolla and androecium not seen; styles in immature fruit ca $2 \mathrm{~mm}$ long, erect and straight, dorsally rounded at apex, the stigma internal and transversely expanded; samara butterfly-shaped, loosely sericeous especially on nut; lateral wings 21-22 $\mathrm{mm}$ high, 14-15 mm wide, trapezoidal, distinct at apex and base; dorsal wing $11 \mathrm{~mm}$ high, 4-5 mm wide, distinct at apex and base; intermediate winglets lacking; ventral areole ovate, 3-3.5 $\mathrm{mm}$ high, 1.6-2.5 $\mathrm{mm}$ wide.

Type. Mexico. Puebla: 20 km SW of Matamoros, Pan American Highway, tropical deciduous forest, 26.XII.1963, immature fruit, J. Cavender s. $n$. (holotype: WIS).

The epithet of Callaeum johnsonii honors David M. Johnson (b. 1955), who published an excellent revision of the genus in 1986. Morphologically, C. johnsonii resembles C. clavipetalum D. M. Johnson, a species known only from two collections from the state of Oaxaca. A complete comparison of the two species is impossible, because $C$. johnsonii is known only in fruit and C. clavipetalum only in flower. However, in C. clavipetalum the stipules are borne much lower, 0.5$1.5 \mathrm{~mm}$ above the base of the petiole; the lamina is adaxially tomentose or velutinous with the raised hairs more or less persistent; the abaxial vesture of the lamina is denser and more twisted; and the bracts and bracteoles are mostly shorter and always much wider relative to their length.

Additional specimen examined. MEXICO. Puebla: Cerro San Isidro, 18.XII.1942, fruit, Miranda 2549 (MEXU).

\section{ACKNOWLEDGMENTS}

The curators of the herbaria MEXU and WIS kindly lent the specimens described in this paper. Karin Douthit drew the illustration.

\section{LITERATURE CITED}

Davis, C. C., C. D. Bell, S. Mathews \& M. J. Donoghue. 2002. Laurasian migration explains Gondwanan disjunctions: Evidence from Malpighiaceae. Proc. Natl. Acad. U.S.A. 99: 6833-6837. 
Anderson: A new species of Callaeum from Puebla, Mexico

Johnson, D. M. 1986. Revision of the neotropical genus Callaeum (Malpighiaceae). Syst. Bot. 11: 335-353.

Niedenzu, F. 1928. Malpighiaceae. In: Das Pflanzenreich IV. 141: 1-870.

Recibido en julio de 2005. Aceptado en noviembre de 2005. 
